Click www.researchjournal.co.in/online/subdetail.html to purchase.

International Journal of Commerce and Business Management Volume 13 | Issue 2 | October, 2020 | 39-43

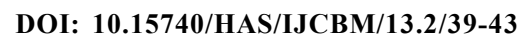

$\Rightarrow$ Visit us : www.researchjournal.co.in

RESEARCH PAPER

\title{
A study on sweet corn buying behaviour of consumers
}

\author{
Baratam Renuka, N.T. Krishna Kishore, I. Bhavani Devi and Y. Lavanya Kumari
}

Received : 11.03.2020; Revised : 01.09.2020; Accepted : 12.09.2020

\begin{abstract}
The present study is intended to understand the buying behaviour of sweet corn consumers. For the study Hyderabad and Vijayawada cities were purposively considering the markets for sweet corn and consumer diversity. A representative sample of sixty sweet corn consumers were selected by using simple random sampling technique from the market. The collected data was analyzed by using appropriate tools like percentage and frequencies and Garrett's ranking. From the investigation it was found that majority of sample consumers preferred to buy sweet corn in raw cob form compared to other forms. Frequency of consumption of sweet corn details revealed that greater percentage of sample consumers were consuming once in a month followed by occasional consumption. Out of the total sample consumer 45 per cent informed that the average monthly consumption is 10-20 cobs. The top preferred reasons for sweet corn purchase were good taste and healthy food. Most preferred place by respondent consumers to purchase sweet corn cobs was from road side vendors followed by small grocery stores.
\end{abstract}

KEY WORDS : Consumer buying behaviour, Sweet corn, Consumer preference

How to cite this paper : Renuka, Baratam, Krishna Kishore, N.T., Bhavani Devi, I. and Lavanya Kumari, Y. (2020). A study on sweet corn buying behaviour of consumers. Internat. J. Com. \& Bus. Manage, 13(2) : 39-43, DOI: 10.15740/HAS/IJCBM/13.2/39-43. Copyright@ 2020: Hind Agri-Horticultural Society.

\section{MEMBERS OF THE RESEARCH FORUM}

Correspondence to:

Baratam Renuka, Institute of Agribusiness Management, S.V. Agricultural College (ANGRAU), Tirupati (A.P.) India

E-mail: renu.baratam@gmail.com

\section{Authors' affiliations:}

N.T. Krishna Kishore and I. Bhavani Devi, Institute of Agribusiness Management, S.V. Agricultural College (ANGRAU), Tirupati (A.P.) India

Y. Lavanya Kumari, Department of Statistics and Computer Applications, S.V. Agricultural College (ANGRAU), Tirupati (A.P.) India 